\title{
The relationship between serum malondialdehyde levels and severity of acne vulgaris on male
}

\author{
Aprilina Dwi Sulistyowati ${ }^{1}$, Dwi Retno Adiwinarni ${ }^{2}$, Kristiana Etnawati ${ }^{2}$ \\ ${ }^{1}$ Polyclinic of Dermatology and Venereology, Pertamina Center Hospital, Jakarta, ${ }^{2}$ Depart- \\ ment of Dermatology and Venereology, Faculty of Medicine, Universitas Gadjah Mada /Dr \\ Sardjito General Hospital, Yogyakarta
}

\begin{abstract}
Acne vulgaris is a multifactorial disorder characterized by seborrhea, microcomedones, comedones, papules, pustules, nodules and possibly scarring. The pathogenesis of acne is not completely understood. Recent studies reported the possible role of reactive oxygen spesies (ROS) especially lipid peroxides in mediating acne inflammation. Malondialdehyde (MDA) is one of the final products of the lipid peroxidation that commonly used as a lipid peroxidation marker. This study was conducted to evaluate the correlation between serum MDA levels and severity of acne on male patients. A total 60 patients with acne who attended in Polyclinic of Department of Dermatology and Venereology, Dr Sardjito General Hospital and met the inclusion and exclusion were involved in the study. The patients were then classified using combined acne severity classification method into three group as mild, modrate and severe acnes. Blood sample were then taken from all subjects and serum MDA levels were determined spectrophotometer. The mean serum MDA levels of severe acne group $(1.85 \pm 0.368 \mu \mathrm{mol} / \mathrm{L})$ were significantly higher than that moderate acne group $(0.79 \pm 0.159$ $\mu \mathrm{mol} / \mathrm{L})(\mathrm{p}=0.000)$ and that mild acne group $(0.52 \pm 0.239 \mu \mathrm{mol} / \mathrm{L})(\mathrm{p}=0.000)$. Moreover, the mean MDA levels of moderate acne group were also significantly higher than that mild acne group $(p=0.002)$. Significantly positive correlation was observed between serum MDA levels and acne lesions total count $(r=0.714 ; p=0.000)$. It can be concluded, there is positive relationship between serum MDA levels and severity of acne vulgaris on male patients.
\end{abstract}

\section{ABSTRAK}

Jerawat adalah penyakit multifaktor yang ditandai dengan seborea, mikrokomedo, komedo, papul, pustula, nodul dan kemungkinan jaringan parut. Patogenesis jerawat belum sepenuhnya diketahui. Penelitian terkini melaporkan kemungkinan peran reactive oxygen species (ROS) khususnya peroksidasi lemak dalam timbulnya inflamasi. Malondialdehid (MDA) adalah hasil akhir peroksidasi lemak yang umumnya digunakan sebagai penanda peroksidasi lemak. Penelitian ini dilakukan untuk mengkaji hubungan antara kadar MDA serum dengan tingkat keparahan jerawat pada pasien laki-laki. Total sebanyak 60 pasien dengan jerawat yang berkunjung ke Poliklinik Bagian Kulit dan Kelamin, RSUP Dr. Sardjito yang memenuhi kriteria inklusi dan eksklusi terlibat dalam penelitian. Pasien dikelompokkan dengan metode combined acne severity classification dalam tiga kelompok yaitu pasien dengan jerawat ringan, sedang dan berat. Sampel darah seluruh pasien diambil dan ditetapkan kadar MDA serumnya dengan spektrofotometer. Rerata kadar MDA serum pasien dengan jerawat berat $(1,85 \pm$ $0,368 \mu \mathrm{mol} / \mathrm{L})$ lebih tinggi secara nyata dibandingan dengan pasien dengan jerawat sedang $(0,79$ $\pm 0.159 \mu \mathrm{mol} / \mathrm{L})(\mathrm{p}=0,000)$ dan pasien dengan jerawat ringan $(0,52 \pm 0,239 \mu \mathrm{mol} / \mathrm{L})(\mathrm{p}=0,000)$.

\footnotetext{
* corresponding author: aprilinadwis@yahoo.com
} 
Selain itu, kadar MDA serum pasien dengan jerawat moderat lebih tinggi secara nyata dibandingkan pasien dengan jerawat ringan $(p=0,002)$. Hubungan positif secara nyata ditunjukkan antara kadar MDA serum dengan angka total lesi jerawat $(r=0,714 ; p=0,000)$. Dapat disimpulkan bahwa ada hubungan positif antara kadar MDA serum dengan tingkat keparahan jerawat pada pasien laki-laki.

Keywords: Acne vulgaris - lipid peroxidation - malondialdehyde - severity - reactive oxygen species

\section{INTRODUCTION}

Acne vulgaris or acne is a multifactorial disorder of childhood and adolescence characterized by seborrhea, microcomedones, comedones, papules, pustules, nodules and possibly scarring. It commonly affects the face, neck, and upper trunk. ${ }^{1,2}$ Even though it is not life threatening disease, it can produce cutaneous and emotional scars. ${ }^{2-4}$ The social, psychological, and emotional impacts of acne have been recognized in the last decade. Acne has been associated with depression, social withdrawal, unemployment, anxiety, suicidal ideation. ${ }^{2,5,6}$

The prevalence of acne in adulescents and adults varies among countries and ethnic groups. In America, acne affects in 90\% of adolescents and continous to affect in $50 \%$ of adult. ${ }^{7,8}$ In China, the prevalence of acne is approximately $46.8 \%$ in adolescents and is not common in adults. ${ }^{9}$ In Nigeria, the prevalence of acne is $76.7 \%$ in students aged $10-13$ years and increases to be $88.2 \%$ and $97.1 \%$ in students aged $14-16$ and $17-19$ years, respectively. ${ }^{10} \mathrm{~A}$ study in Indonesia reported that the prevalence of acne was $68.2 \%$ in students aged $15-16$ years. ${ }^{11}$ It is generally assumed that prevalence of acne varies from 70 to $80 \%$ in adolescents. ${ }^{12,13}$ In Polyclinic of Department of Dermatology and Venereology, Dr Sardjito General Hospital, Yogyakarta, patients with acne vulgaris was the most visitors in two last years.

The pathogenesis of acne is multifactorial and not completely understood. It is widely accepted that acne is an inflammatory disease of pilosebaceous duct that results from four primary pathological processes involving 1) increased sensitivity of the sebaceous glands leading to excessive sebum production; 2) abnormal differentiation and hyperproliferation of the follicular epithelium in the sebaceous glands leading to the formation of microcomedones; 3) proliferation of Propionibacterium acnes within the microcomedones; and 4) subsequent perifollicular inflammation. ${ }^{1,2,14,15}$ Factors influencing the acne severity risk in adolescents and young adults have been reported including family acne history, body mass index, nutritional habits, emotional stress, and menstruation. ${ }^{16,17}$

Recent studies reported the possible role of oxidative stress in mediating acne inflammation. The increase of cutaneous and systemic oxidatives stress in patients with acne has been reported. The reactive oxygen species (ROS) especially lipid peroxides may be an early event that helps to drive the acne process. ${ }^{18,19}$ Moreover, the accumulation of lipid peroxides may be responsible for the inflammatory changes in comedones. These data further supported the previous findings suggesting an association between sebum oxidation and acne progression, strengthening the role of lipid peroxidation in acne pathogenesis. ${ }^{20}$

Malondialdehyde (MDA) is one of the final products of lipid peroxidation. Malondialdehyde level is commonly known as a lipid peroxidation marker. ${ }^{21}$ Several studies reported that the MDA level of patients with acne was significantly higher than that of healthy volonters. ${ }^{19,22,23}$ Furthermore, it was reported that the severity of acne was associated with levels of lipid peroxidation products. ${ }^{24,25}$ This study was conducted to evaluate the relationship between serum MDA levels and the severity of acne in male patients. 


\section{MATERIALS AND METHODS}

\section{Subjects}

This was a descriptive observational study using cross-sectional design conducted in Department of Dermatology and Venereology, Faculty of Medicine, Universitas Gadjah Mada / Dr Sardjito General Hospital, Yogyakarta. Sixty subjects who meet inclusion and exclusion criteria were involved in this study. The inclusion criteria were male patients aged $15-25$ years, diagnosed clinically as acne vulgaris with inflammatory and noninflammatory lesions, willing to participate in this study by signing an informed consent. The exclusion criteria were taking antiinflammatory and hormonal drugs, topical and systemic antibiotics as well as antioxidants, suffering sytemic diseases, smoking, drinking alcohol and doing exercises actively. The study has been proven by the Medical and Health Research Ethics Committee, Faculty of Medicine, Universitas Gadjah Mada, Yogyakarta.

\section{Procedure}

Subjects who attend in the Polyclinic of Department of Dermatology and Venereology, Dr Sardjito General Hospital, Yogyakarta were selected. An explanation concerning the background, objectives and benefit of the study was informed to the patients. Subjects who fulfilled the inclusion and exclusion criteria, an informed consent was given to be signed. Facial phographs of subjects were than taken from three positions i.e. front, right side and left side of faces. Anamnesis and dermatological assessments were conducted to classify the severity of the acne. Blood sample were then taken from all subjects and serum MDA levels were determined.

\section{Acne vulgaris classification}

The severity of the acne was assessed using the Combined Acne Severity Classification (CASC) as conducted by Lehmann et al. ${ }^{26}$ Based on the CASC score, patients were divided into three groups 1) mild acne if found fewer than 20 comedones, or fewer than 15 inflammatory lesions or a total lesion count lower than 30; 2) moderate acne if found 20-100 comedones, or 15-50 inflammatory lesions or a total lesion count of 30125 ; 3) severe acne: if found more than 5 cysts, or comedone count greater than 100 , or a total inflammatory count greater than 50 , or a total lesion count greater than 125 .

\section{Serum MDA levels assay}

Serum MDA levels was measured using spectrophotometry technique (TBARS assay) as previously conducted by Pyles et al. ${ }^{27}$ One $\mathrm{mL}$ serum sample was added $4 \mathrm{~mL}$ thio barbituric acid reagent and incubated in the waterbath at $90^{\circ} \mathrm{C}$ for 80 minutes. Afterward it was cooled on ice for 10 minutes and added $4 \mathrm{~mL}$ butanol. The mixture was then vortexed and centrifuged at $3000 \mathrm{~g}$ for 15 minutes. The supernatant was collected into another tube and read with spectrophotometer (Junior ${ }^{\circledR}$ II Spectrophotometers, Models 6120; Parkin Elmer-Colemen 55) at ë of 510, 532 and $560 \mathrm{~nm}$.

\section{Statistical analysis}

Data were presented as mean \pm standard deviation (SD) or percentage. One way analysis of variance (ANOVA) continued by student t test was used to compare serum MDA levels between the different groups of patients. Pearson's correlation and regression test was used to evaluate the correlation between serum MDA levels and severity of acne. Ap values $<0.05$ was considered as significant. 


\section{RESULTS}

A total 60 patients with acne comprising 20 of each group were involved in the study. Age of subjects ranged from 16 to 25 years and mean of age $20.27 \pm 1.82$ years. The characteristics of subjects are presented in TABLE 1 .

TABLE 1. Characteristics of subjects

\begin{tabular}{lc}
\hline Characteristics & Mean \pm SD or n (\%) \\
\hline Age (years) & $20.27 \pm 1.82$ \\
Education & \\
- High School & $7(11.6)$ \\
- University & $53(89.33 \%)$ \\
\hline
\end{tabular}

The mean serum MDA levels of subjects in each group are presented in TABLE 2 and FIGURE 1. The mean serum MDA levels were significantly different between groups. The mean serum MDA levels of severe acne group (1.85 \pm $0.368 \mu \mathrm{mol} / \mathrm{L}$ ) were significantly higher than that moderate acne group $(0.79 \pm 0.159 \mu \mathrm{mol} / \mathrm{L})(\mathrm{p}=$ $0.000)$ and that mild acne group (0.52 \pm 0.239 $\mu \mathrm{mol} / \mathrm{L})(\mathrm{p}=0.000)$. Moreover, the mean MDA levels of moderate acne group were also significantly higher than that mild acne group $(\mathrm{p}=$ 0.002).

TABLE2. Serum MDA levels (mean \pm SD $\mu \mathrm{mol} / \mathrm{L}$ ) and age (mean \pm SD years) of subjects in each group based on severity of acne vulgaris

\begin{tabular}{lcccc}
\hline Groups & Serum MDA levels & p & Age of subjects & p \\
\hline Mild acne & $0.52 \pm 0.239$ & & $19.95 \pm 1.820$ & \\
Moderate acne & $0.79 \pm 0.159$ & 0.000 & $20.90 \pm 1.997$ & 0.164 \\
Severe acne & $1.85 \pm 0.368$ & & $19.95 \pm 1.538$ & \\
\hline
\end{tabular}

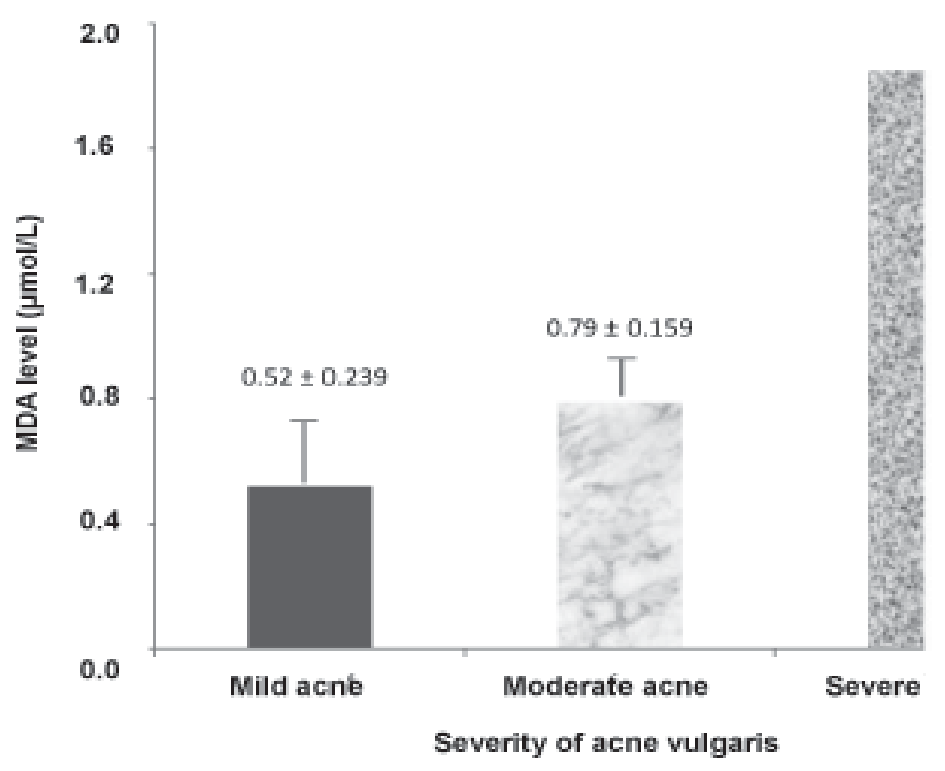

FIGURE 1. Serum MDA levels in each group based on severity of acne vulgaris 
The correlation between serum MDA levels and acne lesions total count is presented in FIGURE 2. Significantly correlation was observed between between serum MDA levels and acne lesions total count $(r=0.714 ; \mathrm{p}=0.000)$.

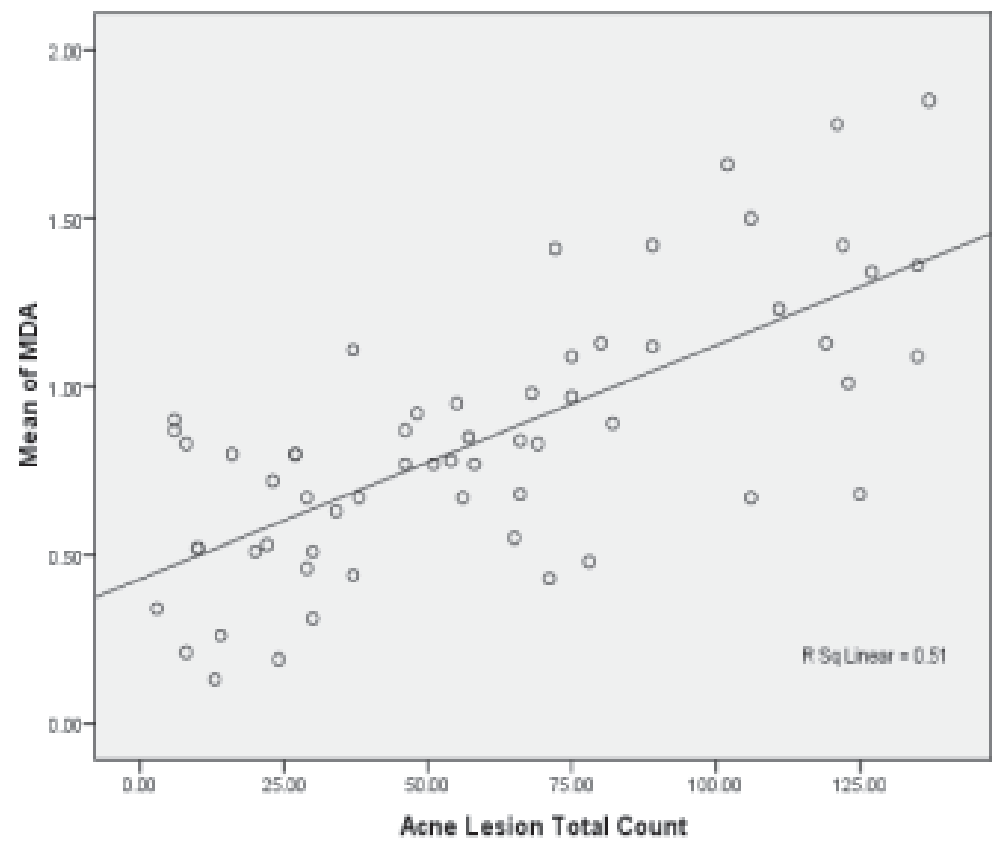

FIGURE 2. Correlation between serum MDA levels and acne lesions total count

\section{DISCUSSION}

Acne is one of the commonest dermatological diseases of childhood and adolescence. Despite technological advances and an increased degree of sophistication within experimental dermatology, the precise pathogenesis of the acne process remain unclear. Inflammation and oxidative stress might set the stage for all subsequent pathogenic factors leading to acne. ${ }^{28}$ Oxidative stress plays an important role in pathogenesis and/or progression of acne. The ROS especially lipid peroxides may be an early event that helps to drive the acne process. ${ }^{18,19}$ In this study the serum MDA levels as lipid peroxidation marker of patients with acne were studied in relation to acne severity. The serum MDA levels were determined using spectrophotometer, whereas the severity of acne was classified using CASC.

Significant differences in serum MDA levels were found in patients with severe acne in compariosn with those with mild and moderate acne in this study. Moreover, significantly correlation was observed between between serum MDA levels and acne lesions total count. These results were in accordance with previous studies reported by some authors. Abdel Fatah et al. ${ }^{24}$ reported that the serum MDA levels were significantly higher in patients with severe acne compare to patients with moderate an mild acne. Furthermore, Sutanto ${ }^{29}$ reported that there was positive correlation between acne severity and MDA level. Whereas Sahib et al. ${ }^{19}$ and Moftah 
et al. ${ }^{30}$ showed that serum MDA levels in patients with acne was significantly higher than in healthy volunteers. The increase of serum MDA levels found in the above studies may support the role of lipid peroxidation in the acne process.

The role of lipid peroxidation in the acne process has been postulated since 50 years ago. In recent years there has been renewed interest in the influence of oxidative stress in acne..$^{28}$ Several studies have been conducted to evaluate other parameters of oxidative stress in relation with acne. A study conducted in patients with papulopustular acne showed that blood antioxidant enzyme activities, including superoxide dismutase (SOD) and glutathione peroxidase (GSH-Px), were significantly lower than controls..$^{19,24,31}$ In addition, the increase oxidative stress burden as reflected in higher catalase and thiobarbituric acid reactive substance (TBARS) levels in patients with acne was also reported. ${ }^{31}$

The emerging studies indicated that low blood SOD, GSH-Px and elevated catalase, TBARS and MDA were characteristic of the patients with acne. These studies clearly showed the existence of oxidative stress in patients with acne vulgaris, and that oxidative stress along with inflammation play a critical role in the pathogenesis of acne.

\section{CONCLUSION}

In conclusion, there is a strong positive correlation between serum MDA levels and severity of acne vulgaris on male patients.

\section{AKNOWLEDGEMENTS}

Authors would like to thank all patients who participated in this study. We would also like to thank Head of Department of Dermatology and Venereology, Faculty of Medicine, Universitas Gadjah Mada /Dr Sardjito General Hospital for the permission to perform the study.

\section{REFERENCES}

1. Zaenglein AL, Thiboutot DM. Acne vulgaris. In: Bolognia JL, Jorizzo JL, Rapini RP, eds. Dermatology. ${ }^{\text {nd }}$ ed. St Louis, MO: Mosby Elsevier. 2008; 495-508.

2. Webster GF. Clinical review acne vulgaris. BMJ. 2002; 325(7362): 475-9.

3. James WD. 2005. Acne. N Eng J Med. 352; (14): 1463-72.

4. Zaenglein AL, Graber EM, Thiboutot DM, Strauss JS. Acne vulgaris and acneiform eruptions. In: Wolff K, Goldsmeith LA, Katz SI, Gilchrest BA, Paller AS, Leffel DJ. Fitzpatrick's dermatology in general medicine. $7^{\text {th }}$ ed. vol I. New York: McGraw-Hill. 2008; 690-703.

5. Barnes LE, Levender MM, Fleischer AB Jr, Feldman SR. Quality of life measures for acne patients. Dermatol Clin. 2012;30:293-300.

6. Dunn LK, O’Neill JL, Feldman SR. Acne in adolescents: quality of life, self-esteem, mood, and psychological disorders. Dermatol Online J. 2011;17(1):1.

7. Yentzer BA, Hick J, Reese EL, Uhas A, Feldman SR, Balkrishnan R. Acne vulgaris in the United States: a descriptive epidemiology. Cutis, 2010;86:94-9.

8. Thiboutot D, Gollnick H, Bettoli V, Dreno B, Kang $\mathrm{S}$, Leyden JJ, et al. New insights into the management of acne: an update from the global alliance to improve outcomes in acne group. J Am Acad Dermatol. 2009; 60(Suppl 5):S1-50.

9. Shen Y, Wang T, Zhou C, Wang X, Ding X, Tian S, et al. Prevalence of acne vulgaris in chinese adolescents and adults: a community-based study of 17,345 subjects in six cities. Acta Derm Venereol. 2012;92(1):40-4.

10. Yahya H. Acne vulgaris in Nigerian adolescents prevalence, severity, beliefs, perceptions, and practices. Int J Dermatol. 2009;48:498-505.

11. Tjekyan RMS. Kejadian dan faktor risiko akne vulgaris. Media Medika Indonesiana. 2008; 43(1): 37-43.

12. Dreno B. Recent data on epidemiology of acne. Ann Dermatol Venereol. 2010; 137(Suppl2): S49-51

13. Ghodsi SZ, Orawa H, Zouboulis CC. Prevalence, severity, and severity risk factors of acne in high school pupils: a community-based study. J Invest Dermatol. 2009; 129(9): 2136-41

14. James WD. Acne. N Eng J Med. 2005; 352(14): 146372 . 
15. Dawson AL, Dellavalle RP. Acne vulgaris. BMJ. 2013; 346:f2634

16. Landro AD, Cazzaniga S, Parazzini F, Ingordo V, Cusano F, Atzori L, et al. Family history, body mass index, selected dietary factors, menstrual history, and risk of moderate to severe acne in adolescents and young adults. J Am Acad Dermatol. 2012; 67(6): 1129-35.

17. Ghodsi SZ, Orawa H, Zouboulis, CC. Prevalence, severity, and severity risk factors of acne in High School Pupils: a community-based study. J Invest Dermatol. 2009; 129 (9):: 2136-41.

18. Bowe WP, Patel N, Logan AC. Acne vulgaris: the role of oxidative stress and the potential therapeutic value of local and systemic antioxidants. J Drugs Dermatol. 2012;11(6):742-6.

19. Sahib AS, Al-Anbari HH, Raghif ARA. Oxidative stress in acne vulgaris: an important therapeutic target. J Mol Pathol. 2013; 2(1):27-31.

20. Ottaviani M, Camera E, Picardo M. Lipid mediators in acne. Mediators Inflamm. 2010;2010. pii: 858176. doi: $10.1155 / 2010 / 858176$.

21. Gawel S, Wardas M, Niedworok E, Wardas P. Malondialdehyde (MDA) as a lipid peroxidation marker. Wiad Lek. 2004; 57(9-10):453-5.

22. Sarici G, Cinar S, Armutcu F, Altinyazar C, Koca R, Tekin NS. Oxidative stress in acne vulgaris. J Eur Acad Dermatol Venereol. 2010; 24(7): 763-7.

23. Arican O, Kurutas EB, Sasmaz S. Oxidative stress in patients with acne vulgaris. Mediators Inflamm. 2005; 2005(6):380-4.
24. Abdel Fattah NSA, Shaheen MA, Ebrahim AA, El Okda ES. Tissue and blood superoxide dismutase activities and malondialdehyde levels in different clinical severities of acne vulgaris. Br J Dermatol. 2008; 159(5):1086-91.

25. Al Shobaili HA, Alzolibani AA, Al Robaee AA, Meki ARMA, Rasheed Z. Biochemical markers of oxidative and nitrosative stress in acne vulgaris: correlation with disease activity. J Clin Lab Anal. 2013; 27:45-52.

26. Lehmann HP, Robinson KA, Andrew JS, Holoway V, Goodman SN. Acne therapy: a methodologic review. J Am Acad Dermatol. 2002; 47(2):231-40.

27. Pyles LA, Stejskal EJ, Einzig S. Spectrophotometric measurement of plasma 2-thiobarbituric acidreactive substances in the presence of hemoglobin and bilirubin interference. Proc Soc Exp Biol Med 1993;202(4):407-19.

28. Bowe WP and Logan AC. Clinical implications of lipid peroxidation in acne vulgaris: old wine in new bottles. Lipids Health Dis. 2010; 9:141:1-6.

29. Sutanto RS. Positive correlation between acne severity and MDA level. [Master Thesis]. Denpasar: Faculty of Medicine, Universitas Udayana.

30. Moftah NH, Hamad WAM, Abd Al Salam FM, Marzouk SA, Said M. Glutathione peroxidase and malondialdehyde in skin lesion of acne vulgaris. J Egyp Women Dermatol Soc. 2009; 8: 25-9.

31. Basak PY, Glutekin F, Kilinc I. The role of the antioxidative defense system in papulopustular acne. J Dermatol. 2001: 28:123-7. 